\title{
Kontekstualisasi Nilai-Nilai Adat Toana Dalam Pembelajaran Sejarah (Studi pada Siswa SMA Negeri 10 Kota Pontianak)
}

\author{
Edwin Mirzachaerulsyah ${ }^{1}$, Andang Firmansyah ${ }^{2}$, Astrini Eka Putri ${ }^{3}$ \\ ${ }^{123}$ Program Studi Pendidikan Sejarah FKIP Universitas Tanjungpura \\ ${ }^{1}$ edwin.mirzachaerulsyah@fkip.untan.ac.id, ${ }^{2}$ andang.firmansyah@ fkip.untan.ac.id, \\ 3astriniekap@fkip.untan.ac.id
}

\begin{abstract}
Adat Toana is part of the historiography of the Mempawah Kingdom where the values in Adat Toana describe the heterogeneous character and characteristics of the Mempawah community, this can be a contextual history learning material for students because it can link the past and its causality for the present. This study aims to (1) what are the values in Adat Toana (2) how to contextualize Adat Toana in learning history. This study uses a qualitative approach with a descriptive study. Data obtained from observations, interviews and documentation studies. The results of this study indicate that Adat Toana has cultural, social and historical values. In teaching the teacher has linked the material of the Indigenous Toana tradition with the material in the textbook, contextualization is carried out by bringing up the narrative of ethnic diversity in Mempawah and the history of the Toana Tradition in Karyaaan Mempawah. Contextualization produces feedback in the form of student responses to the importance of maintaining unity in differences, besides contextualization is oriented towards growing love for local culture.
\end{abstract}

\section{Keywords: Contextualization; History Learning; Toana Customs}

\section{Abstrak}

Adat Toana menjadi bagian dari historiografi Kerajaan Mempawah dimana nilainilai dalam Adat Toana menggambarkan watak dan karakteristik masyarakat Mempawah yang heterogen hal ini dapat menjadi bahan pembelajaran sejarah yang kontekstual pada siswa karena dapat mempertautkan antara masa lalu dan kausalitasnya bagi masa kini. Penelitian ini bertujuan untuk (1) apa saja nilai dalam Adat Toana (2) bagaimana upaya kontekstualisasi Adat Toana dalam pembelajaran sejarah. Penelitian ini menggunakan pendekatan kualitatif dengan studi deskriptif. Data diperoleh dari observasi, wawancara dan studi dokumentasi. Hasil penelitian ini menunjukkan bahwa Adat Toana memiliki nilai budaya, sosial dan sejarah, Dalam pembelajaran guru telah mempertautkan materi tradisi Adat Toana dengan materi dalam buku teks, kontekstualisasi dilakukan dengan memunculkan narasi keragaman etnis yang ada di Mempawah dan sejarah mengenai Tradisi Adat Toana di Kerjaaan Mempawah. Kontekstualisasi menghasilkan feedback berupa respon siswa terhadap pentingnya menjaga persatuan dalam perbedaan, selain itu kontekstualisasi berorientasi pada penumbuhan kecintaan terhadap budaya lokal.

\section{Kata Kunci: Kontekstualisasi; Pembelajaran Sejarah; Adat Toana}

\section{Pendahuluan}

E.H Carr mengatakan bahwa sejarah merupakan sebuah dialog tak berujung antara masa sekarang dan masa lampau (Carr, 1982, p. 30) apa yang dikatakan Carr memiliki makna mendalam bagi sejarawan, pembelajar sejarah maupun mereka yang berminat dalam studi maupun kajian-kajian sejarah. Seorang yang memahami sejarah 
tentunya dia tidak akan "tersesat" atau "terjerembab" dalam permasalahan kompleks di masa kini karena dengan memahami sejarah tentunya ada jalan keluar untuk keluar dari permasalahan tersebut. Tujuan mata pelajaran sejarah menurut Permendikbud Nomor 59 Tahun 2014 salah satunya adalah mengembangkan rasa kebangsaan, cinta tanah air, dan penghargaan kritis terhadap hasil dan prestasi bangsa Indonesia dan ummat manusia di masa lalu. Dari tujuan tersebut dapat diartikan bahwa dalam prosesnya pembelajaran sejarah selalu menekankan pembentukan watak dan sikap mental peserta didik (Kemendikbud, 2014). Pembelajaran sejarah di Sekolah Menengah Atas (SMA) memiliki peran dalam menumbuhkan pendidikan nilai dan karakter yang bersifat membangun kesadaran kritis peserta didik. Nilai-nilai tersebut dapat berasal dari kearifan lokal, tradisi lokal seperti tradisi lisan atau sejarah lisan, nilai kepahlawanan atau ketokohan lokal. Renier mengatakan bahwa sejarah merupakan cerita mengenai pengalaman individu atau manusia yang berada di dalam masyarakat yang beradab (Renier, 1961, p. 81) artinya dalam sebuah komunitas masyarakat terdapat nukilan-nukilan pengalaman dari individu yang dapat diinternalisasikan ke dalam konten atau materi pembelajaran sejarah dan inilah kemudian dapat disebut sebagai sejarah sebagai kisah.

Kearifan lokal sebagai pandangan hidup dan pengetahuan (knowledge) yang dimiliki oleh masyarakat yang kemudian diwujudkan dalam aktivitas-aktivitas pada pemenuhan kebutuhan hidup (Magdalia, 2013, p. 428) aktivitas yang dilakukan oleh masyarakat tersebut memiliki entitas, makna dan nilai yang kemudian menjadi ciri dari kearifan lokal pada masyarakat tersebut hingga kemudian melahirkan kisah, ceritera, hikayat dan folklore. Hal ini kemudian menjadikan kearifan lokal penuh muatan nilai yang dapat di kontekstualisasikan ke dalam pembelajaran sejarah.

Menurut Johnson (2002) kontekstualisasi dalam pembelajaran berhubungan erat dengan dunia peserta didik baik dalam keluarga, masyarakat, lingkungan serta dunia kerja sehingga siswa mampu membuat hubungan antara pengetahuan yang dimiliki dan penerapannya dalam kehidupan sehari-hari. Kontekstualisasi bisa dilakukan dengan mengajarkan muatan kearifan lokal, pendidikan nilai maupun terhadap peristiwaperistiwa sejarah yang aktual. Kontekstualisasi dalam sintak pembelajaran pada dasarnya merupakan proses menghubungkan antara peristiwa, kronologi yang memiliki keterkaitan dengan materi melalui media, model, pendekatan maupun dramaturgi atau sosio drama sehingga dalam prosesnya tidak menghilangkan ciri dan konteks muatan dari peristiwa sejarah tersebut. Adat Toana sendiri merupakan salah satu ritual adat yang dilaksanakan bersamaan dengan pelaksanaan Tradisi Robo-Robo pada Kerajaan Mempawah dimana Adat Toana sendiri dilaksanakan malam hari sebelum puncak acara Tradisi Robo-Robo. Robo-robo sendiri merupakan salah satu tradisi yang memiliki muatan nilai kesejarahan bagi masyarakat Mempawah dimana tradisi tersebut merupakan peringatan kedatangan Opu Daeng Menambon dari Kerajaan Matan ke Kerajaan Bangkule Rajakng (Purmiasih, 2019, p. 50) yang mana pada saat sampai di Muara Sungai Mempawah (Kuala Mempawah) disambut meriah oleh rakyat.

Pelaksanaan Adat Toana sendiri kental dengan unsur kebudayaan Bugis dimana Opu Daeng Menambon berasal dari Luwu Sulawesi Selatan yang merupakan pusat kebudayaan masyarakat Bugis. Opu Daeng Menambon sendiri menggantikan Panembahan Senggaok Raja Bangkule Rajakng (Natsir \& Syamsurizal, 2017, p. 30) yang dahulu bermukim di Sebukit dan kerajaannya masih bercorak adat kebudayaan masyarakat Dayak. Budaya dan adat istiadat masyarakat Bugis kemudian berkembang pesat saat Opu Daeng Menambon berkuasa beberapa adat istiadat bercorak Bugis yang berkembang antara lain Hukum Adat, Adat Siri, Hukum Syara' (Suryani Soren, 2001, p. 33) yang kemudian berpengaruh terhadap corak kehidupan masyarakat Mempawah hingga kini. 
Adat Toana sendiri menurut informan peneliti yang merupakan masyarakat lokal Mempawah sering menyebutnya dengan istilah Betoana atau Betuana. Menurut Natsir (2017, p. 2) Toana berasal dari kata Bertuan yang berarti menyampaikan pesan dari Istana Amantubillah kepada masyarakat bahwa Raja Mempawah akan mengadakan upacara khusus berupa isyarat pemberian gelar melalui ritual adat kerajaan. Artikel ini berusaha menguraikan dan menjelaskan hasil penelitian penulis terkait dengan apa saja nilai-nilai dalam Adat Toana di Kerajaan Mempawah dan bagaimana kontekstualisasinya dalam pembelajaran sejarah pada siswa di SMA Negeri 10 Kota Pontianak.

\section{Metode}

Penelitian ini menggunakan metode kualitatif menurut Moleong (2007, p. 6) penelitian kualitatif merupakan penelitian yang bermaksud untuk memahami fenomena tentang apa yang dialami oleh subjek penelitian antara lain perilaku, persepsi, motivasi, tindakan dan lain sebagainya secara holistik dengan cara mendeskripsikan dalam bentuk kata-kata dan bahasa, pada satu konteks khusus yang alamiah dan dengan menggunakan metode alamiah. Data kualitatif lebih bercirikan kata-kata daripada angka-angka dan hasilnya berupa uraian (Matthew B. Miles, 2014).

Subjek penelitian dalam artikel ini adalah guru sejarah dimana selain sebagai sumber informasi guru juga sebagai pusat pengetahuan bagi siswa. Teknik pengambilan data dalam penelitian ini antara lain dengan observasi, wawancara dan dokumentasi (Matthew B. Miles, 2014; Sugiyono, 2007) selanjutnya adalah menentukan keabsahan data penelitian yakni dengan menggunakan triangulasi sumber dimana sumber beberapa sumber seperti arsip, dokumen, hasil wawancara saling dipertautkan kemudian setelahnya dilakukan reduksi data, penyajian data dan proses penarikan kesimpulan (Matthew B. Miles, 2014).

\section{Hasil dan Pembahasan}

\section{Nilai-Nilai Dalam Adat Toana}

Pelaksanaan ritual Adat Toana sendiri sesungguhnya merupakan upaya mempertahankan eksistensi Kerajaan Mempawah dimana dalam pelaksanaanya khususnya pada saat Panembahan membacakan titah raja selalu menekankan agar selalu menjaga persatuan dan kesatuan kemudian pewarisan budaya dan selalu mengingat akan nilai-nilai dalam sejarah Kerajaan Mempawah. Beberapa nilai yang dapat digali dalam Adat Toana antara lain adalah nilai sosial, nilai budaya dan nilai historis atau kesejarahan.

Persiapan pelaksanaan Adat Toana sendiri dilakukan oleh pihak Keraton Amantubillah Mempawah dengan menghias kompleks Keraton, penggunaan pakaian adat Bugis dan juga Melayu (Telok Belanga). Prosesi Adat Toana sendiri dilakukan selepas Ba'da Isya' dimana tamu-tamu dipersilahkan masuk ke lingkungan Keraton Amantubillah Mempawah. Para tamu di sambut dan diantar ke serambi keraton untuk kemudian diterima oleh Panembahan Mempawah dan selanjutnya mereka dipersilahkan masuk.

Para penerima gelar adat dalam acara Adat Toana sendiri harus memiliki kriteria sebagai berikut (1) mereka yang berjasa pada kemajuan di bidang kebudayaan, (2) berjasa terhadap perkembangan Kerajaan dan masyarakat Mempawah (Natsir \& Syamsurizal, 2017, p. 3) mereka yang diberi gelar juga dari berbagai latar belakang antara lain ada yang berprofesi sebagai Pegawai Negeri Sipil, tokoh adat dan masyarakat, TNI/Polri dan juga utusan dari kerajaan lain. Hal inilah kemudian dalam Adat Toana terdapat nilai-nilai sosial budaya dimana menurut Raven $(1977$, p. 22) nilai sosial sendiri mencakup kasih sayang, tanggung jawab dan kehidupan harmoni. Nilai sosial ini jika di kontekstualisasikan dalam pembelajaran akan dapat menumbuhkan rasa saling mengayomi, menguatkan persatuan dan kesatuan di kalangan peserta didik. 
Pada gelar acara Adat Toana terdapat beberapa representasi kebudayaan yang dihadirkan antara lain representasi kebudayaan Bugis sebagai penyelenggara kegiatan dan representasi kebudayaan dari berbagai etnis yang hadir sebagai tamu undangan. Beberapa tamu undangan berasal dari berbagai suku bangsa atau etnis antara lain Jawa, Tionghoa, Dayak, Melayu dan Bugis. Nilai-nilai yang terkandung dalam representasi ini adalah nilai budaya atau bisa juga nilai sosial budaya dimana peran kebudayaan sebagai hasil manifestasi umat manusia dihadirkan dalam prosesi Adat Toana.

Menurut Koentjaraningrat (1984, p. 85) nilai budaya terdiri dari konsepsikonsepsi yang hidup dalam alam fikiran sebagian besar warga masyarakat mengenai halhal yang mereka anggap amat mulia. Hal tersebut kemudian menjadikan nilai budaya menjadi sesuatu yang dibutuhkan dalam satu tatanan masyarakat yang beradab dan beradat.

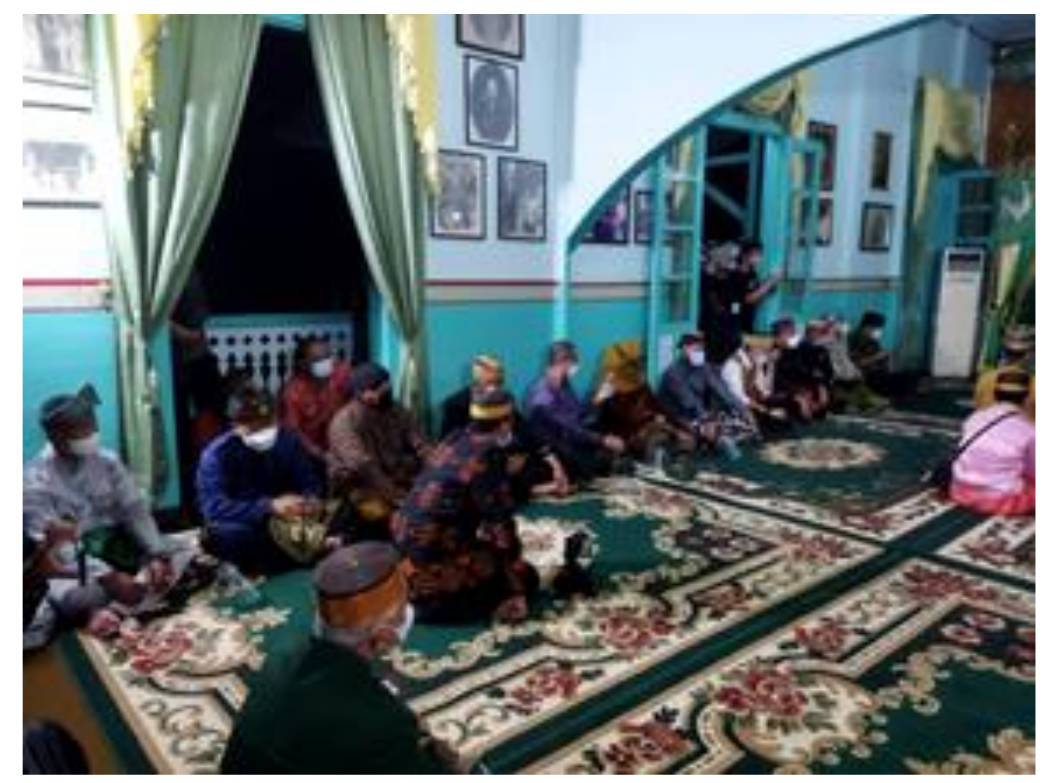

Gambar 1. Representasi Kebudayaan Dari Berbagai Suku/Etnis Seperti Jawa, Dayak, Tionghoa, Melayu, Bugis dalam Adat Toana (Dokumen pribadi)

Nilai historis atau nilai kesejarahan dalam Adat Toana sendiri direpresentasikan melalui penyampaian nukilan-nukilan peristiwa sejarah yang pernah terjadi di Mempawah oleh Panembahan Mempawah dalam pembacaan titah dimana unsur ini merupakan salah satu unsur sejarah lisan. Sejarah lisan sendiri tidak berbeda jauh dengan Tradisi lisan perbedaanya adalah jika tradisi lisan merupakan cara mewariskan sejarah pada masyarakat yang belum mengenal tulisan dan penyampaiannya dalam bentuk pesanpesan verbal berupa pernyataan-pernyataan yang pernah dibuat di masa lampau oleh generasi yang hidup sebelum generasi sekarang (Romadi \& Kurniawan, 2017, p. 85) sedangkan sejarah lisan merupakan sumber sejarah yang dilisankan oleh manusia, pengikut atau yang menjadi saksi akan adanya peristiwa sejarah pada zamannya (Ahmad Adaby, 1997, p. 1).

\section{Kontekstualisasi Nilai Adat Toana Dalam Pembelajaran Sejarah}

Sebagai sebuah peristiwa, sejarah memiliki ciri khas yakni aspek keunikan dan kelampauan. Menurut Ismaun sejarah sebagai peristiwa sering pula disebut sejarah sebagai kenyataan dan serba objektif (2005, p. 279). Adat Toana memiliki nilai-nilai kesejarahan baik dari aspek keunikan maupun kelampauan dimana dalam prosesi Adat Toana dimunculkan narasi sejarah sejarah yakni ceritera mengenai perjalanan panjang 
Keraton Amantubillah dan bagaimana para raja-raja terdahulu mewariskan dan menjaga kearifan lokalnya selain itu dalam proses gelar Adat Toana peninggalan-peninggalan miliki Keraton Amantubillah Mempawah juga dipamerkan dalam lingkungan Keraton seperti meriam, pusaka, pakaian adat, foto-Foto para raja hingga panji-panji kerajaan.

Dalam aspek keunikan terlihat ketika para tamu undangan yang hadir berasal dari berbagai etnis dan suku bangsa. Dimana kemajemukan ini sudah berjalan dari masa lampau di Mempawah. Selain hal tersebut kita ketahui bahwa Mempawah sendiri dahulu pernah menjadi bandar dagang sehingga banyak sekali para pendatang yang mukim atau hanya sekedar transit ke Mempawah. Hal inilah yang kemudian membuat prosesi Adat Toana tak lepas dari narasi sejarah etnis. Seperti sejarah mengenai etnis Cina yang mukim di Mempawah. Mereka bermukim di sekitar Kuala Mempawah hingga daerah Sungai Pinyuh dahulu mereka tergabung dalam Kongsi Lanfang yang berpusat di Mandor (Mary Somers, 2008, p. 65) berawal dari narasi kesejarahan itulah kemudian dapat di kontekstualkan beberapa nilai-nilai antara lain nilai sosial, nilai budaya dan nilai sejarah dalam Adat Toana.

Kontekstualisasi dalam pembelajaran sejarah dapat mendorong peserta didik untuk berpikir historis dan membangun perspektif mereka tentang sesuatu yang dipelajari (Seixas, 2015, p. 94) dalam proses kontekstualisasi nilai dalam Adat Toana peserta didik akan terbangunan memori kolektifnya hingga kemudian memahami esensi dan makna dari pelaksanaan Adat Toana di Keraton Amantubillah Mempawah.

Perencanaan yang dilakukan oleh guru antara lain dengan menyusun perangkat seperti RPP (Rencana Pelaksanaan Pembelajaran), media, materi dan kemudian menyusun alat evaluasi. RPP yang disusun oleh guru pada indikatornya telah ditautkan dengan materi yang membahas mengenai sejarah lokal Mempawah. Pertautan materi pada buku teks dengan pengembangan materi lokal menghasilkan topik-topik sejarah yang menarik. Materi yang diajarkan oleh guru antara lain adalah Perkembangan Kerajaan Bercorak Islam di Kalimantan Barat.

Kontekstualisasi dalam Adat Toana oleh guru sejarah di SMA Negeri 10 Pontianak pada materi diawali dengan menampilkan peristiwa-peristiwa sejarah yang terkait dengan Adat Toana. Beberapa peristiwa yang dimunculkan antara lain peristiwa kedatangan Opu Daeng Menambon di Bangkule Rajakng yang kemudian berlanjut dengan Peristiwa pemindahan pusat kekuasaan dari Sebukit yang merupakan bekas Keraton Kerajaan Bangkule Rajakng ke Kampung Brunai di Pulau Pedalaman Mempawah.

Keterkaitkan antara Adat Toana dengan materi tersebut antara lain adalah Dalam dinamika sejarah Kerajaan Mempawah bahwa walaupaun pusat pemerintahan sempat berpindah namun perayaan dan esensi dari Adat Toana pada masa itu masih tetap dilaksanakan selain karena agar eksistensi kerajaan tidak hilang, kedua adalah agar nilainilai sejarah dan budaya Bugis masih tetap terlestarikan terbukti ketika dalam proses Adat Toana kemudian Panembahan membacakan titah yang berisi narasi-narasi perjalanan sejarah Kerajaan Mempawah. Proses kontekstualisasi tersebut juga dimunculkan oleh guru pada perangkat pembelajarannya antara lain pada Rencana Pelaksanaan Pembelajaran (RPP). Dimana guru berpatokan pada Kompetensi Dasar (KD) 3.8 yang berisi menganalisis perkembangan kehidupan masyarakat, pemerintahan dan budaya pada masa kerajaan-kerajaan Islam di Indonesia serta menunjukkan contoh bukti-bukti yang masih berlaku pada kehidupan masyarakat Indonesia kini. KD ini kemudian dapat diturunkan kedalam indikator antara lain KD 3.8.1 memahami corak kehidupan sosial dan budaya masyarakat pada Kerajaan Mempawah.

Kontekstualisasi dalam nilai budaya antara lain adalah peserta didik diajak menilik mengenai sejarah etnis dan kebudayaan di Kalimantan Barat dimana proses kemajemukan sudah terjalin dari masa lampau. Peristiwa yang diangkat dalam KD.3.8.1 
antara lain adalah adanya corak kesenian budaya yang terdapat pada masyarakat Mempawah antara lain corak budaya Bugis yang dibawa oleh rombongan pengikut Opu Daeng Menambon ketika berhijrah ke Mempawah dari Matan corak tersebut dapat dilihat di Kompleks Keraton Amantubillah Mempawha, nisan makam raja-raja Mempawah di Kampung Brunai dan pakaian adat yang ditampilkan saat acara Adat Toana dimana terdapat beberapa etnis dan suku bangsa yang memakai pakaian adat dengan ciri khasnya masing-masing.

Nilai sosial dimunculkan dalam narasi sejarah sosial kawasan Mempawah seperti perkawinan adat antar etnis dan yang kedua sejarah hubungan sosial antar etnis yang terjadi seperti hubungan antara Kongsi Lanfang di Mandor dengan Kerajaan Mempawah dalam hal pengelolaan tambang emas. Beberap etnis Tionghoa yang tampil dalam relasi hubungan sosial ini antara lain Teochiu dan Hakka (Heidhues, 2008: 17)

Selain itu guru sejarah juga telah menyusun modul pembelajaran yang berbasis muatan sejarah lokal. Modul tersebut telah di ujicobakan dalam proses pembelajaran sejarah sehingga dapat dijadikan pengembangan materi ketika menghadirkan kontekstualisasi nilai Adat Toana dalam pembelajaran sejarah. Bentuk penilaian dan evaluasi yang dilakukan oleh guru antara lain penilaian sikap, penilaian kognitif dan keterampilan. Menurut Arikunto (2006, pp. 9-11) bahwa penilaian dilakukan bertujuan: 1). Merangsang aktivitas siswa 2) menemukan penyebab kemajuan atau kegagalan siswa, guru, maupun proses pembelajaran itu sendiri; 3 ) memberi bimbingan yang sesuai kepada setiap siswa; 4) memberi laporan tentang kemajuan atau perkembangan siswa kepada orangtua dan lembaga pendidikan terkait; dan 5) sebagai feed back program atau kurikulum pendidikan yang sedang berlaku. Dalam proses penilaian guru melihat dari tugas-tugas yang diberikan oleh siswa antara lain hasil diskusi,feedback dari setiap Tanya jawab dengan guru dan penugasan kelompok.

\section{Kesimpulan}

Hasil penelitian yang dilakukan menyatakan bahwa dalam proses kontekstualisasi Adat Toana guru telah memunculkan nilai-nilai yang dapat di sampaikan kepada peserta didik. Kontekstualisasi selanjutnya dalam hal keterkaitan dengan peristiwa sejarah guru telah mampu mengkaitkan antara peristiwa-peristiwa yang terjadi diseputaran lingkaran Kerajaan Mempawah walaupun secara penyampaian masih terdapat kekurangan dalam aspek kronologis. Model pembelajaran yang digunakan masih sebatas model konvensional yakni ceramah dan diskusi dikarenakan situasi yang masih dalam suasana Pandemi Covid-19 sehingga waktu yang diberikan pada saat pembelajaran sejarah sangat terbatas yakni hanya dua sesi dengan satu sesi sebanyak 30 menit. Nilainilai yang disampaikan oleh guru antara lain nilai sosial, nilai budaya dan nilai sejarah. Kontekstualisasi oleh guru juga ditampilkan dalam bentuk video dan gambar seputar prosesi Adat Toana di kelas.

\section{Daftar Pustaka}

Ahmad Adaby, D. (1997). Sejarah Lisan Memburu Sumber Sejarah dari Para Pelaku dan Penyaksi Sejarah. Jurnal Humaniora, IV.

Carr, E. H. (1982). What is History. Alfred A Knopt.

Elaine B, J. (2002). Contextual Teaching and Learning: Menjadikan Kegiatan BelajarMengajar Mengasyikan dan Bermakna. Kaifa.

Ismaun. (2005). Sejarah Sebagai Ilmu. Historia Utama Press.

Kemendikbud. (2014). Peraturan Menteri Pendidikan dan Kebudayaan Republik Indonesia Nomor 59 Tahun 2014 Tentang Kurikulum 2013 Sekolah Menengah Atas/Madrasah Aliyah.

Koentjaraningrat. (1984). Kebudayaan Jawa. Jakarta: Balai Pustaka. 
Magdalia, A. (2013). Potensi Kearifan lokal dalam Pembentukan Jati Diri dan Karakter Bangsa. Ethnicity and Globalization.

Mary Somers, H. (2008). Penambang Emas, Petani dan Pedagang di Distrik Tionghoa Kalimantan Barat. Yayasan Nabil.

Matthew B. Miles, M. H. (2014). Qualitative Data Analysis: An expanded Sourcebook 2nd Edition. In SAGE.

Moleong, L. J. (2007). Metodologi Penelitian Kualitatif. Remaja Rosdakarya.

Natsir, M., \& Syamsurizal. (2017). Ritual Toana Anugrah Raja Amantubillah Mempawah Kalimantan Barat. Kepel Press.

Purmiasih. (2019). Daeng Manambon Sang Penyelamat Dinasti. Pustaka One.

Raven, J. (1977). Education, Values and Society: The Objectives of Educational and The Nature and Development of Competence. HK Lewis \& Co.Ltd.

Renier, G. J. (1961). History: Its Purpose and Method. George Allen \& Unwim, Ltd.

Romadi, \& Kurniawan, G. F. (2017). Pembelajaran Sejarah Lokal Berbasis Folklore untuk Menanamkan Nilai Kearifan Lokal Pada Siswa. Sejarah Dan Budaya, 11.

Seixas, P. (2015). Looking for History. In A. Chapman \& A. Wilschut (Eds.), Joined-Up History; New Directions in History Education Research. Information Age Publishing Inc.

Sugiyono. (2007). Metode Penelitian Pendidikan Pendekatan Kuantitatif, Kualitatif, dan $R \& D$. Alfabeta.

Suharsimi, A. (2006). Prosedur Penelitian : Suatu Pendekatan Praktik, Edisi. Revisi VI. PT. Rineka Cipta.

Suryani Soren, E. (2001). Sejarah Mempawah Dalam Cuplikan Tulisan. Yayasan Penulis 66 Kalimantan Barat. 